UDK 582.929.4:581.19]:544

\title{
EVALUATION OF ANTIOXIDANT ACTIVITY OF THREE LAMIACEAE SPECIES USING THE BRIGGS-RAUSCHER REACTION METHOD
}

\author{
Određivanje antioksidacijske aktivnosti tri vrste familije Lamiaceae primjenom Briggs- \\ Rauscher reakcione metode \\ Śejla Nefić $^{1}$, Sabina Gojak-Salimovic ${ }^{1}$
}

\begin{abstract}
The antioxidant activity of aqueous and aqueous-ethanolic extracts from lemon balm, rosemary and sage leaves were investigated using the Briggs-Rauscher reaction method. This method is based on the inhibitory effects of antioxidants on the oscillations of the Briggs-Rauscher reaction mixture. The extracts from examined plants were prepared using process maceration at room temperature and boiling temperature under reflux conditions. The inhibition times produced by addition of examined plant extracts on an active Briggs-Rauscher reaction mixture were followed potentiometrically. Relative antioxidant activity was determined on the basis of inhibition time using rosmarinic acid as standard. The aqueous extract from sage obtained at boiling temperature under reflux conditions showed the best ability to inhibit oscillations ie. the highest antioxidant activity. The antioxidant activity for six two-component mixtures of aqueous extracts obtained at boiling temperature under reflux conditions was also investigated.
\end{abstract}

Key words: Briggs-Rauscher reaction, Lamiaceae plants, inhibition, antioxidant

\section{INTRODUCTION - Uvod}

The plants of the Lamiaceae family are native in the Mediterranean region, but there are many species in the continental area. Many species are aromatic, culinary and medicinal plants, while some also appear as weeds. Due to their beneficial properties many species are now commercially cultivated wordwide for the need of the pharmaceutical, cosmetic and food industries (BIVAL ŠTEFAN ET AL., 2014; ODAK ET AL., 2015). These plants have antioxidant and anti-inflammatory, even anticarcinogenic properties (SPIRIDON ET AL., 2011; IBRAGIĆ ET AL., 2014).

Lemon balm is a perennial and aromatic plant species of the Lamiaceae family that is native to the Mediterranean region and to Southern Europe. Lemon balm is used as an additive in food, a herbal tea, an ingredient in cosmetics and a medicinal plant (IBRAGIĆ ET AL., 2014). In traditional medicine the lemon balm used as sedeative

\footnotetext{
${ }^{1}$ Faculty of Science, University of Sarajevo
} 
or calming, as spasmolytic and antibacterial agent (ADINEE ET AL., 2009). Its essential oil is used in medicine and pharmacology as an antimicrobial, antitumoral and antioxidant agents, to moderate Alzeheimer's disease and stimulate the immune system (AdINEE ET AL., 2009; MORADKHANI ET AL., 2010). Most of its medicinal properties the lemon balm owes to range of different phenolic compounds, especially phenolic acids such as chlorogenic acid, caffeic acid and rosmarinic acid (IBRAGIĆ ET AL., 2014; ZHENG AND WANG, 2010).

Sage is a perennial and the most aromatic plant species of the Lamiaceae family that is native to the Mediterranean region. The sage tea has been used in traditional medicine for treatment of digestive and circulation disturbances, bronchitis, cough, asthma, angina, mouth and throat inflammations, excessive sweating, skin and many other diseases for a long time (HAMIDPOURET ET AL., 2013). Several studies suggest that sage essential oils might potentially provide novel natural treatments of depression, dementia, obesity, diabetes, lupus, heart disease and cancer (DENT ET AL., 2013; HAMIDPOURET ET AL., 2013; GENERALIĆ ET AL., 2011). Sage is also a natural source of flavonoids and polyphenolic compounds, especiallly phenolic acids such as carnosic acid, rosmarinic acid and caffeic acid possessing strong antioxidant and antibacterial activities (RICE-EVANS ET AL., 1996; RoBARDS ET AL., 1999).

Rosemary is evergreen perennial aromatic plant species of the Lamiaceae family that is native to the Mediterranean region. Rosemary is commonly used as a culinary herb for flavoring, an ingredient in cosmetics and a traditional medicinal plant in the prevention or control of some metabolic disorders like diabetes, heart diseases and certain types of cancers. Several studies demonstrated antioxidant, diuretic, anti-inflammatory, anti-microbial, anti-carcinogenic, hypoglycemic and hypolipidimic activities of rosemary (LABBAN ET AL., 2014). Rosemary contains a number of phytochemicals, including rosmarinic acid, camphor, caffeic acid, ursolic acid, betulinic acid, carnosic acid and carnosol (SRIMANTI AND ASHA, 2017).

Rosmarinic acid is an ester of caffeic acid and 3,4-dihydroxyphenyllactic acid present in several members of the Lamiaceae family. It is a red-orange powder that is slightly soluble in water, but well soluble is most organic solvents. The presence of rosmarinic acid in medicinal plants, herbs and spices has beneficial and health promoting effects. Rosmarinic acid has antioxidant and anti-inflammatory effects and used for the treatment of asthma and reactive airway diseases, allergic disorders such as allergic rhinitis, otitis media, chemical sensitivity and multiple allergen reactivity (STANSBURY, 2014).

In this study, the antioxidant activities of sage (Salvia spp.), lemon balm (Melissa spp.) and rosemary (Rosmarinus spp.) were investigated using the BriggsRauscher reaction method. This method is based on the inhibitory effects by antioxidants on the oscillations of the Briggs-Rauscher reaction mixture. The BriggsRauscher reaction system consists of hydrogen peroxide, malonic acid, manganese(II) sulfate as catalyst, potassium iodate, sulfuric acid and starch as indicator. When antioxidants are added to an active oscillating Briggs-Rauscher reaction mixture there 
is an immediate quenching of the oscilations, an inhibition time occurs which is linearly depedant on the concentration of the antioxidant added, and a subsequent regeneration of the oscillations. The quenching of oscillations is due to the scavenging action of the antioxidant added against the hydroperoxyl radicals forming in the Briggs-Rauscher reaction mixture. Eventually, when the concentration of antioxidant decreases to the point at which hydroperoxyl radicals can multiply, the oscillations resume (CERVELLATI ET AL., 2001). pH of the Briggs-Rauscher reaction mixture is about 2, what is similar to that of the fluids in the human stomach and thus the BriggsRauscher method can give usuful in vitro information on antioxidant activity (HÖNER AND CeRvellati, 2002; HöneR ET AL., 2002). Milos AND MAKOta (2012) demonstrated some new possibilities of Briggs-Rauscher reaction method for determination of synergistic and antagonistic effects in mixture of compounds, which often poses a problem when using standardized methods for determination of the antioxidant activity.

Oscillatory behavior in the Briggs-Rauscher reaction system can be easily followed by colour changes of reaction mixture from colourless over yelow to dark blue and again the same changes, potentiometrically using a iodide-ion-selective electrode or a platinum electrode coupled with a suitable reference electrode (CERVELlatI ET AL., 2001) and spectrophotometrically at $620 \mathrm{~nm}$ (MILOS AND MAKOTA, 2012).

\section{EXPERIMENTAL - Eksperimentalni dio}

\section{Chemicals - Hemikalije}

All chemicals were of analytical grade and were used without further purification. Potassium iodate, sulfuric acid, hydrogen peroxide and ethanol were obtained from Semikem (BiH), malonic acid, manganese(II) sulfate monohydrate and starch were obtained from Merck (Germany) and rosmarinic acid was obtained from Sigma (USA).

\section{Preparation of the solutions for the Briggs-Rauscher reaction - Priprema rastvora za Briggs-Rauscher reakciju}

Three solutions were prepared daily: Solution A: solution of potassium iodate $(0.2 \mathrm{~mol} / \mathrm{L})$ in sulfuric acid $(0.43 \%)$; Solution B: malonic acid $(0.15 \mathrm{~mol} / \mathrm{L})$, manganese(II) sulfate monohydrate $(0.02 \mathrm{~mol} / \mathrm{L})$ and starch $(0.03 \%)$; Solution C: solution of hydrogen peroxide $(15 \% \mathrm{v} / \mathrm{v})$. Mixture of equal volumes of stock solutions (A, B and C) represents the Briggs-Rauscher reaction mixture, which is used for evaluation of antioxidant activity (ALJOVIĆ AND GOJAK-SALIMOVIĆ, 2017).

\section{Preparation of the plants extracts - Priprema biljnih ekstrakata}

Lemon balm and sage were collected in Bosnia and Herzegovina, and rosemary was collected in Croatia. The plant material was air-dried for 20 days and stored at ambient temperature without exposure to direct sunlight. Three different extractions 
were performed as follows: Air dried and powdered leaves $(1 \mathrm{~g})$ were extracted with $50 \mathrm{~mL}$ of mixture water:ethanol 1:1 (v/v) for 30 minutes (extract 1) and with $50 \mathrm{~mL}$ boiled water for 20 minutes (extract 2 ) at room temperature. Air dried and powdered leaves $(2 \mathrm{~g})$ were extracted with boiled water $(100 \mathrm{~mL})$ under reflux conditions for 20 minutes (extract 3 ). Each extract was rapidly filtered and filled according to the calibrated volume flask. The stock solutions obtained (filtered extract of $20 \mathrm{mg}$ plant in $1 \mathrm{~mL}$ solvent) were stored in the fridge at $4^{\circ} \mathrm{C}$ until analysis.

\section{Preparation of the standard solutions - Priprema standardnih rastvora}

A stock solution of rosmarinic acid $(100 \mathrm{mg} / \mathrm{L})$ was prepared daily by dissolving pure rosmarinic acid in distilled water. Standard solutions of rosmarinic acid with concentrations ranging between 10 and $60 \mathrm{mg} / \mathrm{L}$ were obtained by diluting the stock solution with the respective volumes of distilled water.

\section{Apparatus - Aparatura}

Oscillations of the Briggs-Rauscher reaction mixture were followed potentiometrically by recording the potential of a platinum wire electrode and $\mathrm{Ag} / \mathrm{AgCl} / \mathrm{KCl}_{\text {(sat) }}$ reference electrode (Phywe, Model 18475.00). The electrodes were connected to a $\mathrm{pH}$ multimeter (Phywe, Model 13702.93). The accuracy of the multimeter was $\pm 1 \mathrm{mV}$. All measurements were conducted at temperature $\left(25 \pm 0.5^{\circ} \mathrm{C}\right)$ using a suitable thermostated system. The reaction mixture was stirred by a magnetic stirrer $(600 \mathrm{rpm})$.

Procedure for determination antioxidant activity by Briggs-Rauscher reaction method - Procedura određivanja antioksidacijske aktivnosti BriggsRauscher reakcionom metodom

The Briggs-Rauscher reaction mixture were prepared by mixing $10 \mathrm{~mL}$ of each stock solutions ( $\mathrm{A}, \mathrm{B}$ and $\mathrm{C}$ ) in the thermostated beaker equipped with a magnetic stir bar and placed on stirring plate. The order of addition was: solution A, solution B and solution C. Oscillations start after the addition of solution C. After the third oscillation, $1 \mathrm{~mL}$ of a suitably diluted plant extract was added to $30 \mathrm{~mL}$ of an active Briggs-Rauscher reaction mixture. Typical potentiometric recordings for a noninhibited and an inhibited Briggs-Rauscher reaction mixture are shown in Figure 1 and Figure 2. The inhibition times were then measured from the recordings. The inhibition time $\left(t_{\text {inhib }}\right)$ is defined as the time elapsed between the end of addition of the diluted extract and the time first regenerated oscillation (CERVELLATI ET AL., 2001). 


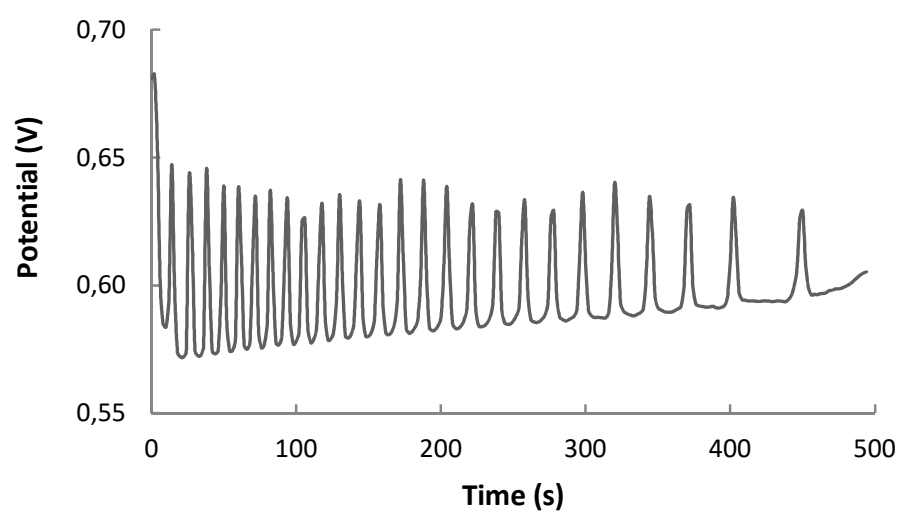

Figure 1. Recording of the potential versus time of non-inhibited Briggs-Rauscher reaction Slika 1. Promjena potencijala sa vremenom neinhibirane Briggs-Rauscher reakcije

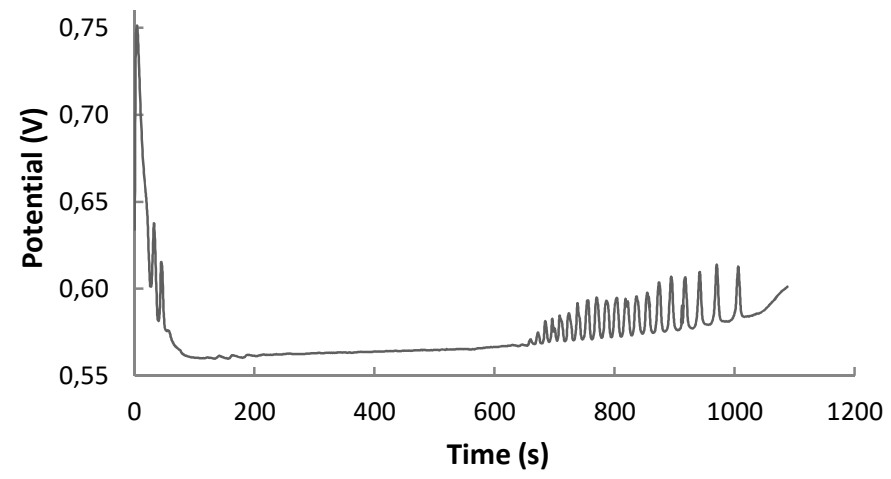

Figure 2. Recording of the potential versus time of inhibited Briggs-Rauscher reaction Slika 2. Promjena potencijala sa vremenon inhibirane Briggs-Rauscher reakcije

\section{RESULTS AND DISCUSSION - Rezultati i diskusija}

To measure antioxidant activity of an extract, suitable dilutions were performed to obtained inhibition time falling in the range of linearity (Figure 3), when $1 \mathrm{~mL}$ of the diluted extract was added to $30 \mathrm{~mL}$ of the active Briggs-Rauscher reaction mixture.

For all samples the inhibition times increased with increasing concentration of extracts. The linear behaviour of the inhibition time versus concentration of extracts 3 added are shown in Figure 3 for plants studied. 


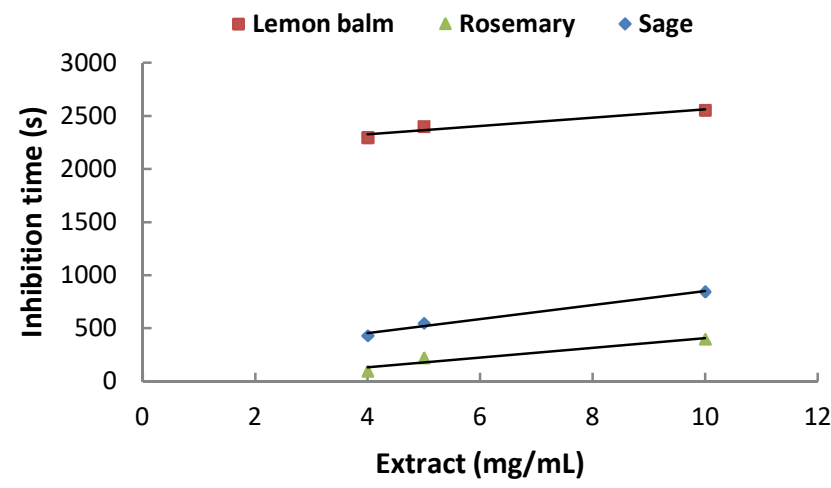

Figure 3. Inhibition time versus concentration of the extracts 3

Slika 3. Zavisnost vremena inhibicije od koncentracije ekstrakata 3

The parameters of the straight lines together with $R^{2}$ values reported in Table 1.

Table 1. Parameters of straight-lines equations $t_{\text {inhib }}=m($ extract $)+q$ and $R^{2}$ values for extracts Tabela 1. Parametri pravca jednačine $t_{i n h i b}=m($ ekstrakt $)+q i R^{2}$ vrijednosti za ekstrakte

\begin{tabular}{|c|c|c|c|}
\hline Extract of sage & $m\left(\mathrm{mg}^{-1} \mathrm{~mL} \mathrm{~s}\right)$ & $q(\mathrm{~s})$ & $R^{2}$ \\
\hline 1 & 8.871 & 146.5 & 0.998 \\
\hline 2 & 42.11 & 901.9 & 0.900 \\
\hline 3 & 39.00 & 2171 & 0.933 \\
\hline Extract of lemon balm & $m\left(\mathrm{mg}^{-1} \mathrm{~mL} \mathrm{~s}\right)$ & $q(\mathrm{~s})$ & $R^{2}$ \\
\hline 1 & 11.50 & 68.50 & 0.994 \\
\hline 2 & 71.39 & -101.4 & 0.999 \\
\hline 3 & 65.97 & 109.9 & 0.985 \\
\hline Extract of rosemary & $m\left(\mathrm{mg}^{-1} \mathrm{~mL} \mathrm{~s}\right)$ & $q(\mathrm{~s})$ & $R^{2}$ \\
\hline 1 & 105.3 & -283.7 & 0.994 \\
\hline 2 & 108.1 & -332.6 & 0.996 \\
\hline 3 & 45.40 & -47.90 & 0.930 \\
\hline
\end{tabular}

As shown in Table 1, the slopes of the straight lines are different, so the calculation of the relative antioxidant activity will depend on the substance chosen as standard and the concentration of the sample. Rosmarinic acid (RA) was chosen as standard. The straight line for rosmarinic acid is

$$
t_{\text {inhib }}(\mathrm{s})=52038\left(\mathrm{mg}^{-1} \mathrm{~mL} \mathrm{~s}\right) \times \text { conc }-372.3(\mathrm{~s}) \quad R^{2}=0.944
$$

in the concentration range from $0.01-0.06 \mathrm{mg} / \mathrm{mL}$.

Relative Briggs-Rauscher antioxidant activity (BRAI) is the ratio between concentrations of the chosen standard (std) and samples (smp) that give the same inhibition time: 
$\mathrm{BRAI}=[\mathrm{std}] /[\mathrm{smp}]$

The mass concentration of the standard [std] that should give the same inhibition time of the sample was calculated from equation (1). Results are expressed as mg rosmarinic acid equivalents per grame of dry extract. The obtained BRAI values of the extracts 1-3 concentration of $5 \mathrm{mg} / \mathrm{L}$ are reported in Table 2 .

Table 2. BRAI values of the extracts obtained of different procedures Tabela 2. Vrijednosti BRAI za ekstrakte dobijene različitim procedurama

\begin{tabular}{|c|c|c|c|}
\hline Extract of sage & Dry weight $\mathbf{( g / m L )}$ & $\boldsymbol{t}_{\text {inhib }}(\mathbf{s})$ & BRAI \\
\hline 1 & 0.0010 & 192 & 43.3 \\
2 & 0.0026 & 1161 & 45.3 \\
3 & 0.0041 & 2402 & 52.0 \\
\hline Extract of lemon balm & Dry weight $\mathbf{( g / m L )}$ & $\boldsymbol{t}_{\text {inhib }}(\mathbf{s})$ & BRAI \\
\hline 1 & 0.0014 & 129 & 27.5 \\
2 & 0.0021 & 258 & 23.0 \\
3 & 0.0032 & 548 & 22.1 \\
\hline Extract of rosemary & Dry weight $\mathbf{( g / m L )}$ & $\boldsymbol{t}_{\text {inhib }}(\mathbf{s})$ & BRAI \\
\hline 1 & 0.0020 & 270 & 24.7 \\
2 & 0.0035 & 186 & 12.2 \\
3 & 0.0032 & 222 & 14.3 \\
\hline
\end{tabular}

The dry weight of extract 3 for lemon balm is higher than that of extracts 1 and 2 , but its activity is lower. Also, the dry weight of extract 2 for rosemary is higher than that of extracts 1 and 3, but its activity is lower. It is means that in the extracts 1 and 2 for lemon balm and in the extracts 1 and 3 for rosemary a larger amounts of substances without antioxidant activity are present.

The antioxidant activity decreased in the following order: sage extract $>$ lemon balm extract $>$ rosemary extract for each extraction procedure. The extract 3 for sage showed the best ability to inhibit oscillations, ie. the highest antioxidant activity comparing to all other extracts.

Althought the antioxidant activity of extracts of sage, lemon balm and rosemary have been widely ivestigated, the results of different studies are difficult to compare, usually because of different sample preparation procedures and the used methods. GenERALIĆ ET AL. (2011) studied antioxidant properties of Dalmatian sage used DPPH, FRAP and the Briggs-Rauscher reaction methods. They found for sage extracts that inhibition time of Briggs-Rauscher oscillations was between 6.93-15.69 minutes and BRAI index between 0.88-2.5 mg GAE/L. GeNeralić MeKINIĆ ET AL. (2014) studied antioxidant properties of five Laminaceae plant extracts using different methods. They found that inhibition time of Briggs-Rauscher oscillations was 18.3 minutes for sage extract and 38.2 minutes for lemon balm extract. Šljıvo et al. (2016) evaluated antioxidant activity of selected medicinal plants using the Briggs-Rauscher reaction method. They found for rosemary extracts that inhibition time of BriggsRauscher oscillations between 26-275 seconds and BRAI index between 3.00-31.7 mg 
GAE/g dry plant. JAKELIĆ (2016) determined antioxidant activities of six aqueous plant extracts (St. John's Wort, sage, lavender, thyme, lemon balm and marigold) using DPPH and the Briggs-Rauscher reaction methods. The highest antioxidant activity measured by the Briggs-Rauscher method was for the lemon balm (344.5 mg GAE/g).

Each plant extract contains a different phenolic compounds resulting in varying levels of total antioxidant activity. The total antioxidant activity was measured as the inhibition time of the Briggs-Rauscher reaction. In order to evaluate the impact of interactions among extracts on their antioxidant acitivity, the inhibition time of individul extract 3 concentration $5 \mathrm{mg} / \mathrm{mL}$ was compared with the values obtained by mixing them in different combinations. The obtained results are reported in Table 3.

Table 3. Inhibitory effects of various mixtures of extracts 3

Tabela 3. Inhibitorski efekti različitih smjesa ekstrakata 3

\begin{tabular}{|l|c|}
\hline \multicolumn{1}{|c|}{ Combination of extracts } & $\boldsymbol{t}_{\text {inhib }}(\mathbf{s})$ \\
\hline rosemary + sage $(50 \%: 50 \%)$ & $1420(673)$ \\
rosemary + lemon balm $(50 \%: 50 \%)$ & $623(222)$ \\
lemon balm + sage $(50 \%: 50 \%)$ & $1949(709)$ \\
rosemary + sage $(62.5 \%: 37.5 \%)$ & $1054(551)$ \\
rosemary + lemon balm $(62.5 \%: 37.5 \%)$ & $479(213)$ \\
lemon balm + sage $(62.5 \%: 37.5 \%)$ & $1542(596)$ \\
\hline
\end{tabular}

*The values in parentheses are the summations of antioxidant activity of individual extract

The results obtained experimentally for different combinations of extracts 3 were compared with theoretical values calculated by adding up the effects of two individual extracts 3 analyzed separately. Our results indicate that all mixtures to some extent showed a difference in antioxidant activity when compared to the theoretical values. It is evident that all combinations of two extracts 3 showed synergistic effect. The sinergism between extracts in the mixture makes that antioxidant activity not only depedant on the concentrations, but also on the structure and interactions between the antioxidants present in the extracts.

\section{CONCLUSIONS - Zaključci}

The Briggs-Rauscher oscillating reaction is suitable as an analytical method to determine relative antioxidant activity of pure compounds or extracts of natural sources of antioxidans. For all samples the inhibition times increased with increasing concentration of extracts. The aqueous extract from sage obtained at boiling temperature under reflux conditions showed the best ability to inhibit oscillations ie. the highest antioxidant activity. The antioxidant activity decreased in the following order: sage extract $>$ lemon balm extract $>$ rosemary extract for each extraction procedure. All combinations of two-component mixtures of aqueous extracts obtained at boiling temperature under reflux conditions showed some level of discrepancy in antioxidant activity when compared to individual values of their constituents. 


\section{REFERENCES - Literatura}

Adinee, J., PIRI, K., Karami, O. 2009: Essential Oil Composition of Lemon Balm (Melissa Officinalis L.) Leaves Grown in Hamadan Province, Iran. Medicinal and Aromatic Plant Science and Biotehnology, 3(1): 58-60.

ALJOVIĆ, I., GoJAK-SALIMOVIĆ, S. 2017: Evaluation of the antioxidant activity of ferulic, homovanillic and vanillic acids using the Briggs-Rauscher oscillating reaction method. Bulletin of the Chemists and Technologists of Bosnia and Herzegovina, 49: 35-38.

Bival Štefan, M., Vuković Rodríguez, J., Blažeković, B., KindL, M., VladimiRKNEŽEVIĆ, S. 2014: Total Hydroxycinnamic Acids Assay: Prevalidation and Application on Lamiaceae Species. Food Analytical Methods, 7(2): 326-336.

Cervellati, R., Höner, K., Furrow, S.D., Neddens, C., Costa, S. 2001: The BriggsRauscher Reaction as a Test to Measure the Activity of Antioxidants. Helvetica Chimica Acta, 84(12): 3533-3547.

Cervellati, R., Renzulli, C., Guerra, M.C., Speroni, E. 2002: Evaluation of Antioxidant Activity of Some Natural Polyphenolic Compounds Using the Briggs-Rauscher Reaction Method. Journal of Agricultural and Food Chemistry, 50(26): 7504-7509.

Dent, M., Dragović-Uzelac, V., Penić, M., Brnčić, M., Bosiljkov, T., LeVaJ, B. 2013: The Effect of Extraction Solvents, Temperature and Time on the Composition and Mass Fraction of Polyphenols in Dalmatian Wild Sage (Salvia officinalis L.). Food Technology and Biotechnology, 51(1): 84-91.

Hamidpour, M., Hamidpour, R., Hamidpour, S., Shahlari, M. 2014: Chemistry, Pharmacology, and Medicinal Property of Sage (Salvia) to Prevent and Cure Illnesses such as Obesity, Diabetes, Depression, Dementia, Lupus, Autism, Heart Disease, and Cancer. Journal of Traditional and Complementary Medicine, 4(2): $82-88$.

Höner, K., Cervellati, R., Neddens, C. 2002: Measurements of the in vitro antioxidant activity of German white wines using a novel method. European Food Research and Technology, 214(4): 356-360.

Höner, K., CERVELLATI, R. 2002: Measurements of the antioxidant capacity of fruits and vegetables using the BR reaction method. European Food Research and Technolology, 215(5): 437-442.

Generalić, I., Skroza, D., LJubenkov, I., Katalinić, A., Burčila, F., Katalinić, V. 2011: Influence of the phenophase on the phenolic profile and antioxidant properties of Dalmatian sage. Food Chemistry, 127: 427-433.

Generalić Mekinić, I., SKRoza, D., LJubenkov, I., Šımat, V., Smole MožINA, S., KATALINIĆ, V. 2014: In vitro Antioxidant and Antibacterial Activity of Lamiaceae Phenolic Extracts: A Correlation Study. Food Technology and Biotechnology, 52(1): 119-127.

IBRAgić, S., SAlihović, M., TAHIROVIĆ, I., TOROMANOVIĆ, J. 2014: Quantification of some phenolic acids in the leaves of Melissa officinalis L. from Turkey and 
Bosnia. Bulletin of the Chemists and Technologists of Bosnia and Herzegovina, 42: 47-50.

JAKELIĆ, M. 2016: Jednostavni i parcijalno-linearni regresijski modeli primijenjeni na različitim svojstvima vodenih biljnih ekstrakata. Diplomski rad, Prehrambenobiotehnološki fakultet, Sveučilište u Zagrebu.

LABban, L., Mustafa U.E.S., IBRAHIM, Y.M. 2014: The Effects of Rosemary (Rosmarinus officinalis) Leaves Powder on Glucose Level, Lipid Profile and Lipid Perodoxation. International Journal of Clinical Medicine, 5: 297-304.

MILOS, M., MAKOTA, D. 2012: Investigation of antioxidant synergisms and antagonisms among thymol, carvacrol, thymoquinone and $p$-cymene in a model system using the Briggs-Rauscher oscillating reaction. Food Chemistry, 131(1): 296-299.

Moradkhani, H., Sargsyan, E., Bibak, H., Naseri, B., Sadat-HosseinI, M., FayaziBARJIN, A., MeftAhIZADE, H. 2010: Melissa oficinalis L., a valuable medicine plant: A review. Journal of Medicinal Plants Research, 4(25): 2753-2759.

Odak, I., Talić, S., Martinović Bevanda, A. 2015: Chemical composition and antioxidant activity of three Lamiaceae species from Bosnia and Herzegovina. Bulletin of the Chemists and Technologists of Bosnia and Herzegovina, 45: 2330.

Rice-Evans, C.A., Miller, N.J., Paganga, G. 1996: Structure-antioxidant activity relationship of flavonoids and phenolic acid. Free Radical Biology and Medicine, 20(7): 933-956.

Robards, K., Prenzler, P.D., Tucker, G., Swatsitang, P., Glover, W. 1999: Phenolic compounds and their role in oxidative processes in fruits. Food Chemistry, 66(4): 401-436.

SPIRIDON, I., BODIRLAU, R., TEACA, C.A. 2011: Total phenolic content and antioxidant activity of plants used in traditional Romanian herbal medicine. Central Europian Journal of Bilogy, 63(3): 386-396.

SRIMANTI, P., ASHA, J.R. 2017: Evaluation of Analgesic Activity of Essential Oil of Rosmarinus officinalis and its Comparison with That of Aspirin: An Experimental Study. Research Journal of Pharmaceutical, Biological and Chemical Sciences, 8(3): 1965-1970.

StANSBURY, J. 2014: Rosmarinic Acids a Novel Agent in the Treatment of Allergies and Asthma. Journal of Restorative Medicine, 3(1): 121-126.

ŠLJIVO, E., DžOMBA, E., GOJAK-SALIMOVIĆ, S. 2016: Evaluation of antioxidant activity of selected medicinal plants using the Briggs-Rauscher oscillating reaction. Bulletin of the Chemists and Technologists of Bosnia and Herzegovina, Special issue, 125.

Zheng, W., WANG, S.Y. 2001: Antioxidant Activity and Phenolic Compounds in Selected Herbs. Journal of Agricultural and Food Chemistry, 49(11): 51655170 . 


\begin{abstract}
SAŽETAK
Antioksidacijska aktivnost vodenih i vodeno-etanolnih ekstrakata iz lišća matičnjaka, ruzmarina i kadulje ispitivana je primjenom Briggs-Rauscher reakcione metode. Ova metoda se bazira na inhibitorskom efektu antioksidanasa na oscilacije BriggsRauscher reakcione smjese. Efekat se sastoji u trenutačnom zaustavljanju oscilacija, vremenu inhibicije i ponovnoj regeneraciji oscilacija. Vrijeme inhibicije linearno zavisi od koncentracije i vrste dodanog antioksidansa. Sa porastom koncentracije ekstrakata linearno se povećavalo vrijeme inhibicije. Vodeni ekstrakti kadulje dobijeni na temperaturi ključanja uz refluks su pokazali najbolju sposobnost inhibicije oscilacija tj., najveću antioksidacijsku aktivnost. Antioksidacijska aktivnost ekstrakata je opadala prema nizu kadulja > matičnjak > ruzmarin nezavisno od načina ekstrakcije. Također je ispitana i antioksidacijska aktivnost šest dvokomponentnih smjesa vodenih ekstrakata dobijenih na temperaturi ključanja uz refluks.
\end{abstract}

Corresponding author: Sabina Gojak-Salimović, Department of Chemistry, Faculty of Science, University of Sarajevo, Zmaja od Bosne 33-35, 71000 Sarajevo, Bosnia and Herzegovina,e-mail: sgojak@pmf.unsa.ba 